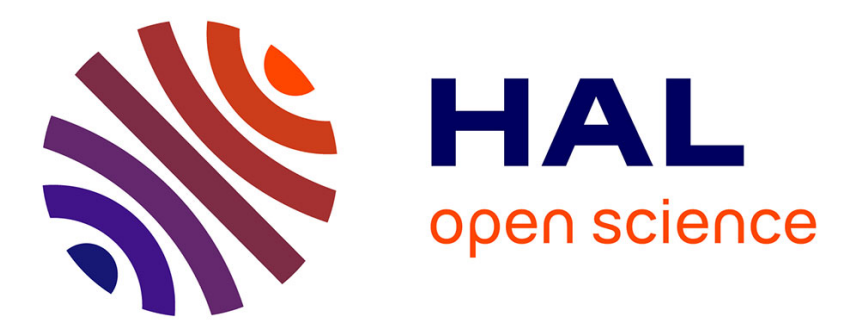

\title{
Upstream discharge distribution in compound-channel flumes
}

D. Bousmar, N. Rivière, Sébastien Proust, André Paquier, R. Morel, Y. Zech

\section{To cite this version:}

D. Bousmar, N. Rivière, Sébastien Proust, André Paquier, R. Morel, et al.. Upstream discharge distribution in compound-channel flumes. Journal of Hydraulic Engineering, 2005, 131 (5), p. 408 p. 412. 10.1061/(ASCE)0733-9429(2005)131:5(408) . hal-00842385

\section{HAL Id: hal-00842385 https://hal.science/hal-00842385}

Submitted on 8 Jul 2013

HAL is a multi-disciplinary open access archive for the deposit and dissemination of scientific research documents, whether they are published or not. The documents may come from teaching and research institutions in France or abroad, or from public or private research centers.
L'archive ouverte pluridisciplinaire HAL, est destinée au dépôt et à la diffusion de documents scientifiques de niveau recherche, publiés ou non, émanant des établissements d'enseignement et de recherche français ou étrangers, des laboratoires publics ou privés. 


\title{
UPSTREAM DISCHARGE DISTRIBUTION IN COMPOUND-CHANNEL FLUMES
}

\author{
D. Bousmar ${ }^{1}$, N. Rivière ${ }^{2}$, S. Proust ${ }^{3}$, A. Paquier ${ }^{4}$, R. Morel $^{5}$ and Y. Zech ${ }^{6}$
}

\begin{abstract}
Common inlet design for compound-channel flumes does not ensure a proper upstream discharge distribution. As the total head in the upstream tank is the same for both main-channel and floodplain subsections, the velocity in the upstream section is also the same in both subsections. The floodplain discharge is therefore too large and a mass transfer towards the main channel occurs along the flume. This note investigates how long a compound-channel flume must be to ensure that equilibrium between subsection discharges is achieved. The required length is found to be significant compared to the actual length of experimental flumes reported in the literature.
\end{abstract}

CE Database subject headings: Boundary conditions; Experimental data; Flood plains; Flow distribution; Flumes; Uniform flow; Velocity distribution.

\footnotetext{
${ }^{1}$ Formerly Postdoctoral Researcher, Fond National de la Recherche Scientifique, Belgium; now Engineer, Hydraulic Research Laboratory, Ministère Wallon de l'Equipement et des Transports, Rue de l'Abattoir, 164, 6200 Châtelet, Belgium. E-mail: dbousmar@met.wallonie.be.

${ }^{2}$ Assistant Professor, LMFA, INSA de Lyon, Av. Einstein, 20, 69621 Villeurbanne Cedex, France. E-mail: riviere@insa-lyon.fr.

${ }^{3}$ Research Engineer, PhD Student, Hydrology-Hydraulics unit, Cemagref Lyon, Quai Chauveau, 3 bis, CP 220 69336 Lyon Cedex 09, France. E-mail: proust@1yon.cemagref.fr.

${ }^{4}$ Researcher, Hydrology-Hydraulics unit, Cemagref Lyon, Quai Chauveau, 3bis, CP 220 - 69336 Lyon Cedex 09, France. E-mail: paquier@lyon.cemagref.fr.

${ }^{5}$ Professor, LMFA, INSA de Lyon, Av. Einstein, 20, 69621 Villeurbanne Cedex, France. E-mail: robert.morel@insa-lyon.fr.

${ }^{6}$ Professor, Dept. of Civil and Environmental Engineering, Hydraulics Unit, Université catholique de Louvain, Place du Levant, 1, 1348 Louvain-la-Neuve, Belgium. E-mail: zech@gce.ucl.ac.be.
} 


\section{INTRODUCTION}

Much research has been devoted to flow in a compound channel. Experiments on prismatic compound channels highlighted the momentum transfer between main channel and floodplains that decreases the total conveyance (see e.g. Sellin 1964, Shiono and Knight 1991). Further experiments also explored the more complex geometry of meandering compound channels, characterized by mass and momentum transfers, and by secondary currents due to both cross-over flow and curvature (Sellin et al. 1993). Recently researchers studied intermediate situations consisting of a local non-prismaticity or an obstacle in a prismatic geometry, focusing on mass-transfer effects without the meander-curvature influence (Proust et al. 2002, Bousmar et al. 2004).

In the latter case, the uniform flow upstream of the obstacle turns out to be difficult to establish in a compound-channel flume of moderate length. It is known that a distance is required for the boundary-layer development (Schlichting 1968, Ranga Raju et al. 2000). The new experiments highlight that an even longer distance is necessary to equilibrate the discharge distribution between main-channel and floodplain subsections. In uniform-flow conditions, it is observed that the water-surface level $z_{w}$ is almost the same in each subsection, at least at measurement precision. This level is fixed by the downstream condition; and the interaction between subsections prevents the development of any significant transverse surface slope. On the other hand, the velocity is generally lower in the floodplain than in the main channel. Usually, main channel and floodplains are supplied from the same tank through a curved transition zone (Fig. 1a). The head $H$ is therefore the same in each inlet subsection and, as the water level $z_{w}$ across the section has been shown to be almost constant, the kinetic head $U^{2} / 2 g$ and the velocity $U$ are also the same (Fig. 2). As a 
result, the floodplain discharge in the upstream section exceeds the discharge corresponding to uniform flow and a mass transfer develops from floodplain towards main channel.

To the authors' knowledge, this problem has never been addressed in the literature regarding either prismatic or meandering compound-channel experiments. For the latter, the meandering channel generates such mass transfers that the intake influence is limited to a short part of the flume. In the prismatic geometries, attention is usually paid to the development of the boundary layer and the measurement section is chosen in the downstream half of the flume (Rajaratnam and Ahmadi 1979, Knight and Demetriou 1983, Myers 1987, Myers et al. 1991, Smart 1992). When addressed, the setting of uniform-flow conditions only concerns the adjustment of the water-surface level using a tailgate (Sellin 1964, Myers and Elsawy 1975, Knight and Demetriou 1983). The evolution of the discharge distribution itself is not discussed, although some results show an actual mass transfer either in subsection discharge values (Sellin 1964, Table 1) or in the secondary-current pattern in a cross section (Shiono and Knight 1991, Fig. 11).

New measurements of this discharge distribution along a prismatic channel are presented in this note. Some estimations of the required flume length are given, considering the actual uniform-flow development from both water-surface level and subsection-discharge equilibrium viewpoints. Lastly, technical solutions are proposed to improve the inlet conditions in compound-channel flumes.

\section{EXPERIMENTAL RESULTS}

Discharge distribution measurements were performed in three experimental compoundchannel flumes: (1) at Compagnie Nationale du Rhône (CNR), Lyon, France; (2) at 
Université catholique de Louvain (UCL), Louvain-la-Neuve, Belgium; and (3) at Laboratoire de Mécanique des Fluides et d'Acoustique (LMFA), Lyon, France. Table 1 summarizes the characteristics of these flumes. Their length to width ratio was low but still in the range found in the literature (e.g. Shiono and Knight 1991). Total discharges were measured using electromagnetic flowmeters on the supply pipes, and local velocities were recorded using a micro propeller in CNR and LMFA flumes, and a pitot tube in UCL flume. Flow depths were measured using point gauges; and the downstream level was adjusted using the tailgate, attempting to obtain uniform-flow condition, i.e. setting the water surface parallel to the channel bed. Table 2 summarizes flow conditions investigated.

In a first stage, both CNR and UCL flumes were supplied through a classical curved transition zone (Fig. 1a), thus without upstream discharge-distribution control. Figure 3 shows the typical evolution of the transverse distribution of depth-averaged velocity along CNR flume. Although the water surface was generally parallel to the channel bed, the flow was clearly not uniform. The velocity was almost constant across the section closest to the inlet, due to the fixed water head $H$ in the upstream tank. Main-channel and floodplain velocity then increased and decreased respectively along the channel length. This resulted in a noticeable mass transfer from floodplain to main channel. Prior to any further experiments, the subsection inlets were separated (Fig. 1b) and a sill was constructed in the floodplain of the inlet cross-section, in an attempt to reduce its discharge. The flow conditions so obtained were closer to uniform flow, reducing the mass transfer. The sill-level adjustment remained sensitive, but this enabled the correct investigation of the flow in geometries with obstacles (Proust et al. 2002). 
Similar results were obtained in the UCL flume with classical inlet. Figure 4a shows the evolution of the discharge distribution along the channel and, again, a mass transfer appears from floodplains to main channel. Further experiments were then performed with a separate inlet for each subsection. In the UCL case, the discharge distribution was adjusted using variable opening screens that enabled control of each subsection supply. The discharge distribution was first fixed according to the distribution found in the downstream part of the flume for the experiments without upstream control (Fig. 4b). The scattering of the plot for the lower discharge $Q=8 \mathrm{l} / \mathrm{s}$ is due to the small flow depth and the resulting sensitivity to bed level unevenness. As small mass transfers were still observed for the larger discharges, the procedure of fixing the upstream discharge distribution according to previous downstream measurements was repeated and, this time, the flow was found almost uniform (Fig. 4c). The existence of an asymptotic equilibrium distribution was confirmed by the following experiment: the floodplain discharge was now forced to be smaller than in equilibrium condition. A mass transfer was then observed from main channel to floodplains, as shown in dotted lines on Figure $4 \mathrm{~b}$, and the discharge distribution converged to the previous equilibrium distribution, demonstrating its uniqueness.

Uniform flow conditions were considered as fully developed when the discharge distribution, computed as the ratio between floodplain and total discharge, presented discrepancies lower than $1 \%$ between successive stations. The distance $L_{u}$ necessary to establish uniform flow for the UCL flume using a classical inlet was therefore estimated in the range $7 \mathrm{~m}$ to $14 \mathrm{~m}$ (Table 2). No establishment length could be estimated for the lower discharge, due to the data scattering mentioned above. Longer flumes were required for higher discharges and floodplain flow depths, as higher mass transfer were necessary. This criterion appeared significantly more critical than the length required to obtain a fully- 
developed boundary layer. The latter was estimated in the range $2 \mathrm{~m}$ to $5 \mathrm{~m}$, depending also on discharge and flow depth (Schlichting 1968, Ranga Raju et al. 2000).

Lastly, the LMFA flume was fitted with two separate inlets with separate flowmeters. The floodplain discharge was first fixed according to prediction by the DEBORD model (Nicollet and Uan 1979), then increased by $30 \%$ and $50 \%$. Again, a mass transfer occurred from floodplain to main channel and a longer distance was required to get equilibrium for the larger perturbation (Fig. 5). In the LMFA flume, separate tailgates were also used for each subsection. This made the conservation of a correct discharge distribution possible till the very end of the flume. This seemed also to reduce the distance necessary for uniform-flow establishment, when compared to UCL flume (Table 2).

\section{DISCUSSION}

The number of data available on the establishment length for uniform flow $L_{u}$ is too limited to develop a general law giving this length as a function of some selected geometrical or hydraulic parameters. Moreover, such a law would be of limited practical use, as it has been shown that it is possible and more advantageous to adapt the inlet section of the flume to adjust the discharge distribution. The establishment length is simply made nondimensional to enable comparison with the geometry of the flumes reported in the literature. This non-dimensional form is obtained by dividing the length $L_{u}$ by the floodplain width $B$. Indeed, for a larger floodplain width, the mass transfer is supposed to require a longer establishment length.

Experimental values of the ratio $L_{u} / B$ are reported in Table 2. While the ratio increases with flow depth for the UCL flume, it remains constant and lower for the LMFA flume, 
probably thanks to the use of separate tailgates for each subsection. This makes impossible any precise conclusion. Nevertheless, it is suggested suitable to consider the maximum value of $L_{u} / B=35$ as the limit above which the discharge distribution certainly corresponds to uniform flow conditions. A survey of the geometry of several experimental flumes reported in the literature indicates that, for most of them, their actual total length $L$, or station of the measurement section $L_{m}$ when available, does not fulfill this criteria (Table 3). As no controls of the discharge distribution were reported by these authors, those data should be used with awareness. Since most of these flumes are probably no longer fitted with their compoundchannel cross section, only $2 \mathrm{D}$ or $3 \mathrm{D}$ numerical modeling could help to validate a posteriori those data from the discharge distribution point of view. Alternatively, further work could also be devoted to assess more precisely the suggested criteria, using numerical simulations for some typical prismatic compound channel sections.

\section{CONCLUSIONS}

Boundary conditions for subcritical flows are classically given by the upstream total discharge and the downstream flow depth. For compound-channel flows, theoretical considerations of the head in the channel subsections and experiments on the evolution of the discharge distribution between subsections clearly show that this discharge distribution should also be accounted for as an upstream boundary condition. This should obviously be considered when using 1-D or 1-D network models of floodplain flows, as it is usually done in $2 \mathrm{D}$ and $3 \mathrm{D}$ modeling. When the actual discharge distribution is unknown, an additional channel reach should be modeled upstream of the area of interest, with a length sufficient to enable correction of this distribution. The suggested criteria of a minimum length to floodplain width ratio $L / B>35$ could serve as a first and conservative indication for this purpose. 
The control of the discharge distribution is also necessary for experiments in compoundchannel flumes. When only straight prismatic geometries are considered, a sufficient length enables the discharge distribution to reach equilibrium through mass transfer between floodplain and main channel. The suggested criteria of $L / B>35$ would imply that some formerly published experimental data would need to be revisited and possibly critically revised. For working flumes that would be too short, control of the upstream discharge distribution is found possible by a separation of each subsection inlet, allowing a progressive adjustment of the subsection discharges.

\section{ACKNOWLEDGEMENTS}

Experiments in CNR and LMFA flumes were funded by PNRH99-04 research programme. D. Bousmar and S. Proust travel costs were supported by the Tournesol programme grant 02947VM funded by EGIDE, France and CGRI, Communauté française de Belgique. 


\section{APPENDIX I. REFERENCES}

Bousmar, D., Wilkin, N., Jacquemart, J.-H. and Zech, Y. (2004). "Overbank flow in symmetrically narrowing floodplains." J. Hydr. Engrg., ASCE, 130(4), 305-312.

Knight, D.W. and Demetriou, J.D. (1983). "Flood plain and main channel interaction." J. Hydr. Div., ASCE, 109(8), 1073-1092.

Myers, W.R.C (1987). "Velocity and discharge in compound channels." J. Hydr. Div., ASCE, 113(6), 753-766.

Myers, W.R.C., Brennan, E.K., Wormleaton, P.R., Merrett, D.J., Knight, D.W., Shiono, K., Elliott, S.C.A. and Sellin, R.H.J. (1991). "Reply by the authors to the discussion on four companion papers". J. Hydr. Res., IAHR, Delft, The Netherlands, 29(2), 272-276.

Myers, W.R.C. and Elsawy, E.M. (1975). "Boundary shear in channel with flood plain." J. Hydr. Div., ASCE, 101(7), 933-946.

Nicollet, G. and Uan, M. (1979). "Ecoulements permanents à surface libre en lits composés." La Houille Blanche, Grenoble, France, 35(1), 21-30 (in French).

Proust, S., Rivière, N., Bousmar, D., Paquier, A. and Morel, R. (2002). "Velocity measurements in a concrete experimental channel representing a flood plain." Proc. Hydr. Meas. and Exp. Meth., Eastes Park, Colorado, ASCE, CD-Rom.

Rajaratnam, N. and Ahmadi, R.M. (1979). "Interaction between main channel and floodplain flows." J. Hydr. Div., ASCE, 105(5), 573-588.

Ranga Raju, K.G., Asawa, G.L. and Mishra, H.K. (2000). "Flow-establishment length in rectangular channels and ducts." J. Hydr. Engrg., ASCE, 126(7), 533-539.

Schlichting, H. (1968). Boundary-layer theory, 6th Ed., McGraw-Hill, New-York.

Sellin, R.H.J (1964). "A laboratory investigation into the interaction between the flow in the channel of a river and that over its flood plain." La Houille Blanche, Grenoble, France, 20(7), 793-802. 
Sellin, R.H.J., Ervine, D.A. and Willetts, B.B. (1993). "Behaviour of meandering two-stage channels." Proc. I.C.E., Water, Maritime and Energy, Thomas Telford, London, 101(2), 99-111.

Shiono, K. and Knight, D.W. (1991). "Turbulent open channel flows with variable depth across the channel." J. Fluid Mech., 222, 617-646.

Smart, G.M. (1992). "Stage-discharge discontinuity in composite flood channels." J. Hydr. Res., IAHR, Delft, The Netherlands, 30(6), 817-833. 


\section{APPENDIX II. NOTATIONS}

The following symbols are used in this paper :

$B$ = floodplain width;

$g \quad=\quad 9.81 \mathrm{~m} / \mathrm{s}^{2}$, gravity constant;

$H=$ total head;

$h \quad=\quad$ flow depth;

$h^{*}=\left(h-h_{b}\right) / h$, relative water depth;

$h_{b}=$ bankfull depth;

$L \quad=\quad$ flume length;

$L_{m}=$ distance between flume inlet and measurement section;

$L_{u}=$ length necessary to establish uniform flow;

$n=$ Manning roughness coefficient;

$Q=$ discharge;

$U=$ depth-averaged longitudinal velocity;

$x=$ longitudinal direction;

$y=$ transverse direction;

$z \quad=\quad$ vertical direction; and

$z_{w}=$ water-surface level.

\section{Subscripts}

$f p \quad=\quad$ floodplain; and

$m c=$ main channel. 


\section{List of figure captions}

Fig. 1. Compound-channel flume inlet: (a) Classical inlet common for main channel and floodplain, with curved transition zone; and (b) Separate inlets.

Fig. 2. Water surface, head and velocity profiles in a compound-channel flume with classical inlet, near inlet and at a distance downstream: (a) side view; and (b) plan view.

Fig. 3. CNR flume, discharge $Q=150 \mathrm{l} / \mathrm{s}$ : transverse distribution of depth-averaged velocity $U$ at given stations $x$.

Fig. 4. UCL flume: evolution of the discharge distribution with (a) classical inlet without discharge distribution control; (b) separate inlets with discharge distribution control, stage 1; and (c) separate inlets with discharge distribution control, stage 2. Upstream discharge distributions in (b) and (c) were forced to be almost similar to the measured downstream distributions in (a) and (b), respectively. Dotted lines on (b) correspond to tests with reduced upstream floodplain discharge. Abscissa labels in italic correspond to a virtual flume obtained by considering each measurement series in (b) and (c) as equivalent to the measurements that would be obtained in a longer flume.

Fig. 5. LMFA flume: evolution of the discharge distribution. Dotted lines correspond to tests with increased upstream floodplain discharge. 
Table 1: Flume characteristics.

\begin{tabular}{l|l|l|l}
\hline Flume name & CNR & UCL & LMFA \\
\hline Length $L(\mathrm{~m})$ & 14 & 10 & 8 \\
Width (m) & 3.00 & 1.20 & 1.20 \\
Slope (-) & $1.9010^{-3}$ & $0.9910^{-3}$ & $1.8010^{-3}$ \\
\# of floodplains (-) & 1 & 2 & 1 \\
Floodplain width $B(\mathrm{~m})$ & 2.20 & 0.40 & 0.80 \\
Bankfull depth $h_{b}(\mathrm{~m})$ & 0.160 & 0.050 & 0.051 \\
Bed material & Smoothed cement & Coated plywood & PVC \\
Manning roughness $n\left(\mathrm{~s} / \mathrm{m}^{1 / 3}\right)$ & $0.0119-0.0132$ & 0.0107 & 0.0091 \\
\hline
\end{tabular}


Table 2: Flow conditions investigated.

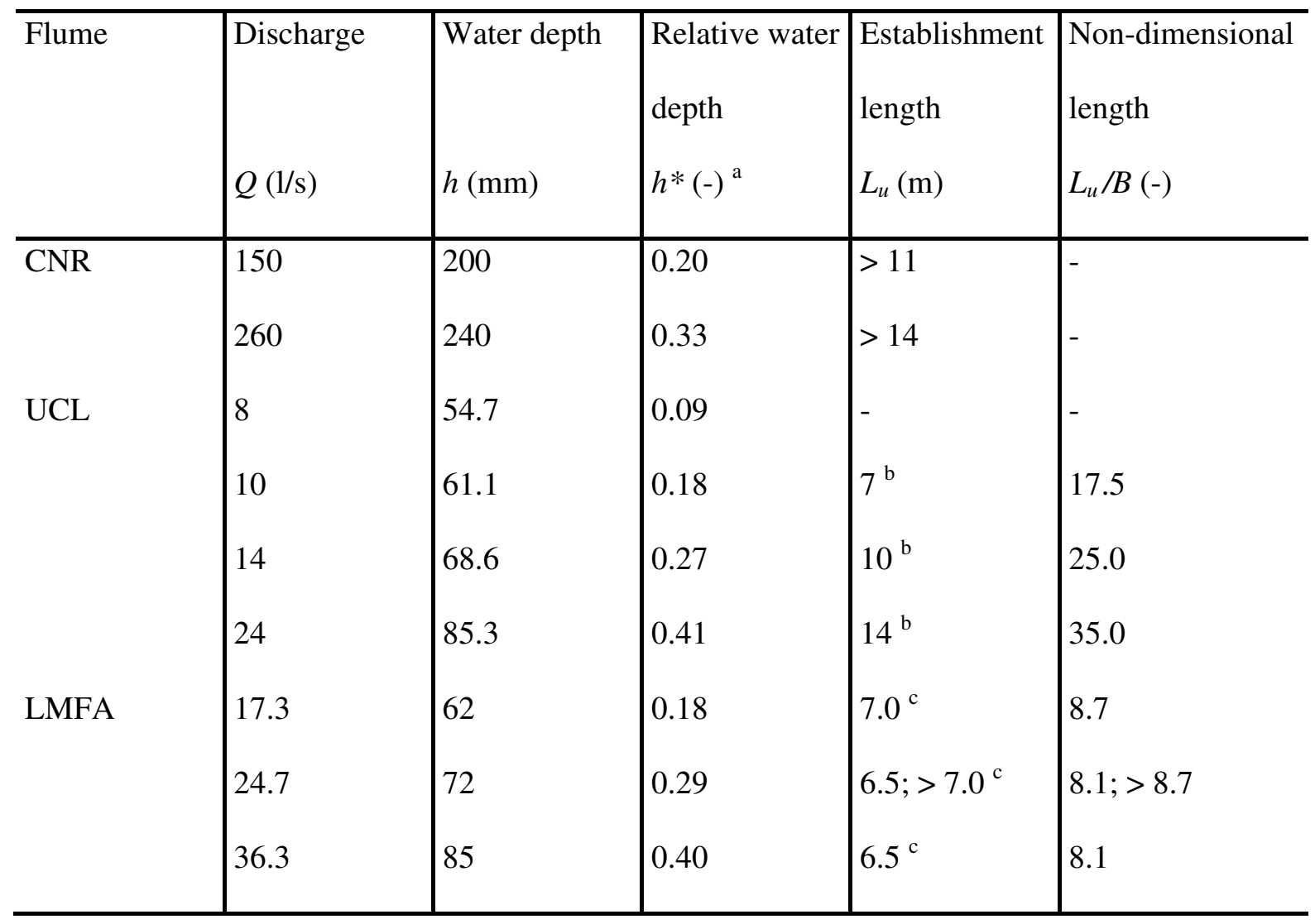

${ }^{\mathrm{a}}$ where $h^{*}=\left(h-h_{b}\right) / h$, and $h_{b}=$ bankfull depth.

${ }^{\mathrm{b}}$ from curved transition zone.

${ }^{c}$ from artificially perturbed discharge distribution. 
Table 3: Geometrical parameters of some flumes reported in the literature.

\begin{tabular}{l|l|l|l|l|l}
\hline Authors & Relative & Flume & Meas. & Floodplain & Non-dim. \\
water depth & length & station & width & length \\
& $h^{*}(-)$ & $L(\mathrm{~m})$ & $L_{m}(\mathrm{~m})$ & $B(\mathrm{~m})$ & $L / B(-)^{\mathrm{a}}$ \\
\hline Knight and Demetriou 1983 & $0.10-0.50$ & 15 & 12 & $0.076 ; 0.229$ & $158 ; 52$ \\
Myers 1987 & $0.15-0.50$ & 9 & - & 0.30 & 30 \\
Myers et al. 1991, Shiono and & $0.05-0.50$ & 56 & - & $1.50 ; 3.35$ & $37 ; 17$ \\
$\quad$ Knight 1991 & $0.10-0.40$ & 11 & - & 0.36 & 31 \\
Myers and Elsawy 1975 & $0.12-0.40$ & 18 & 9 & 0.51 & 18 \\
Rajaratnam and Ahmadi 1979 & $0.09-0.15$ & 4.57 & $2.30 ; 3.36$ & 0.17 & $13 ; 20$ \\
Sellin 1964 & $0.05-0.12$ & 20 & 16 & $0.75 ; 1.15$ & $21 ; 14$ \\
\hline
\end{tabular}

${ }^{\text {a }} L_{m} / B$, where $L_{m}$ is available. 


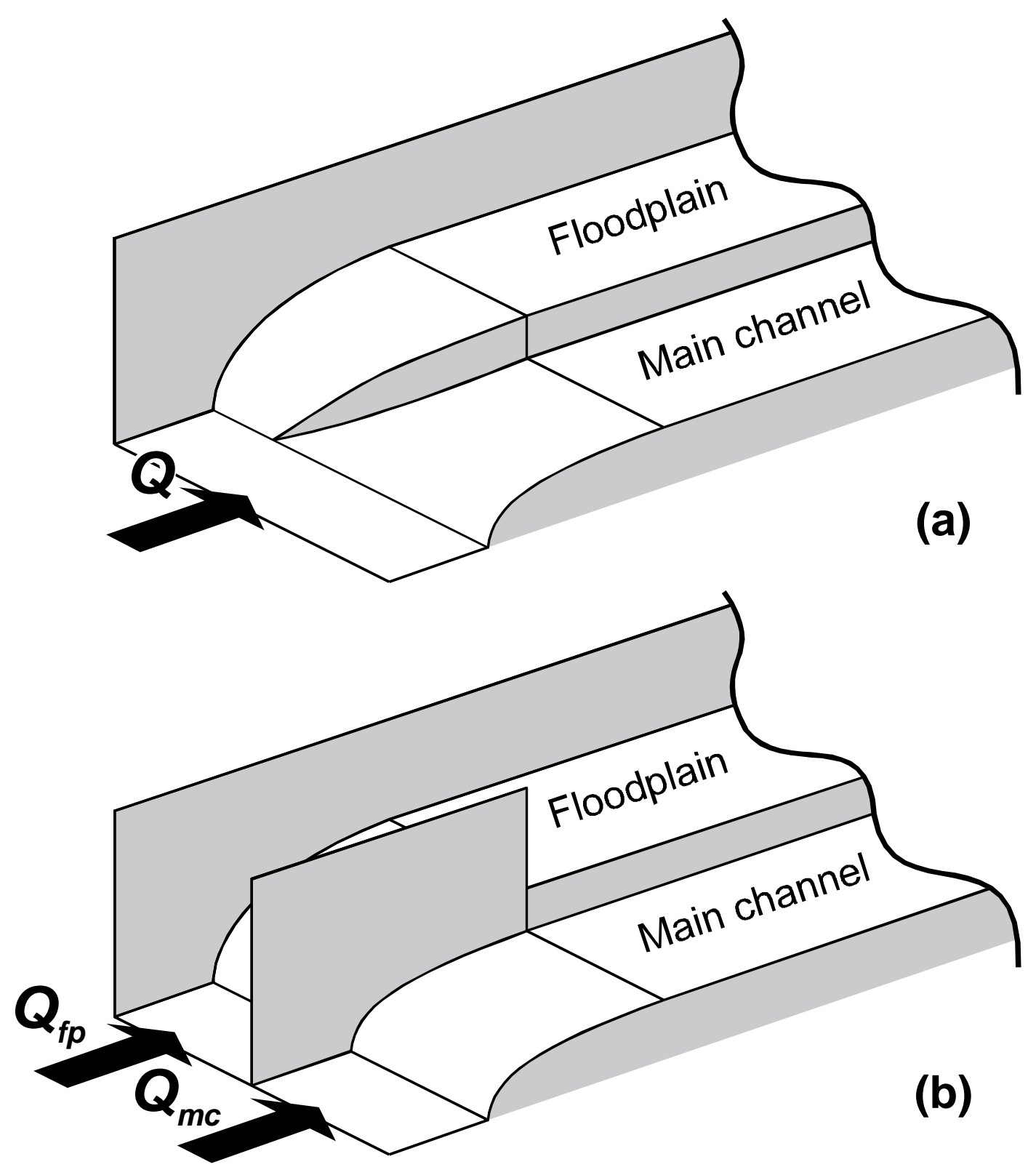

Fig. 1 

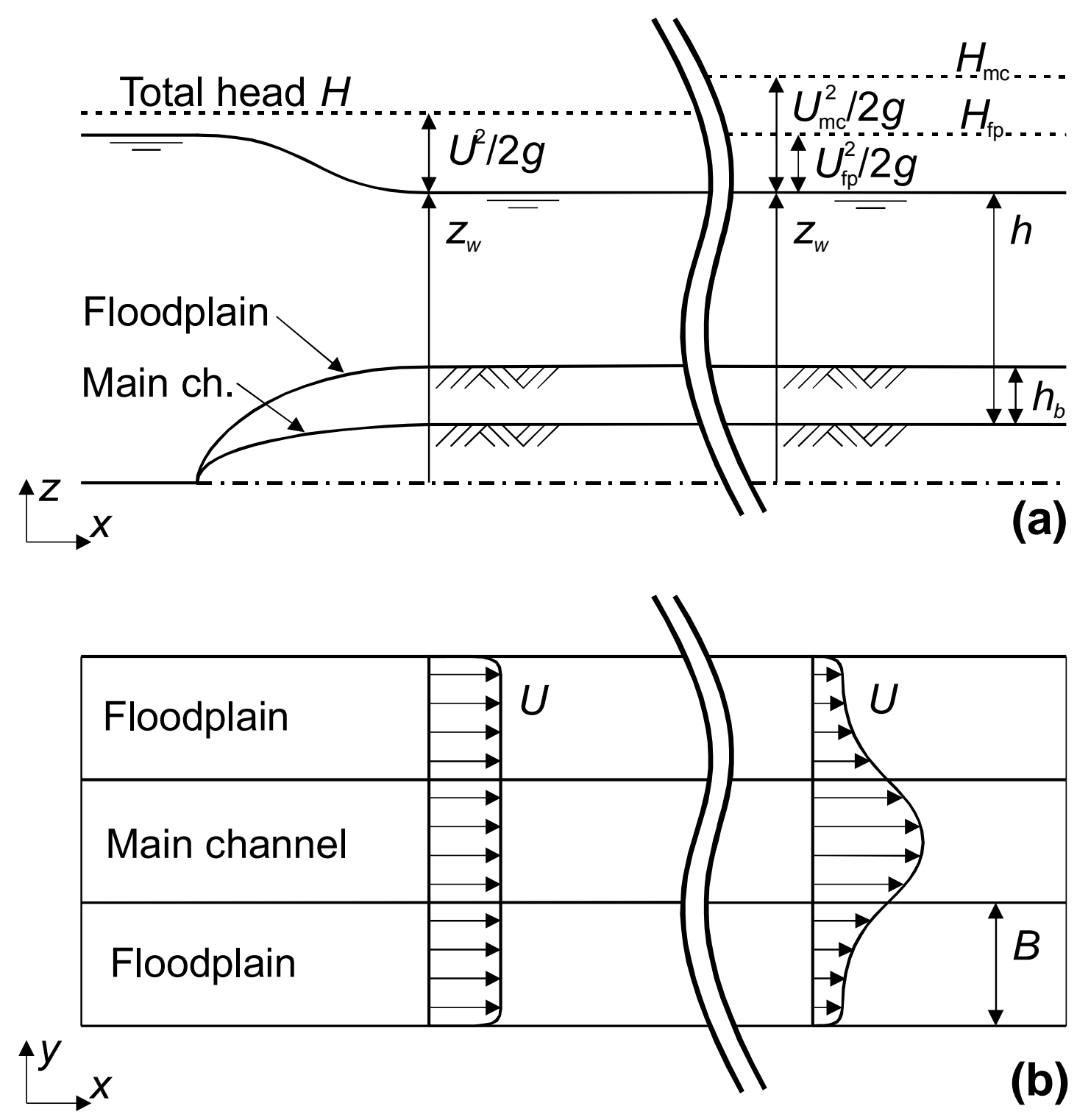

Fig. 2 


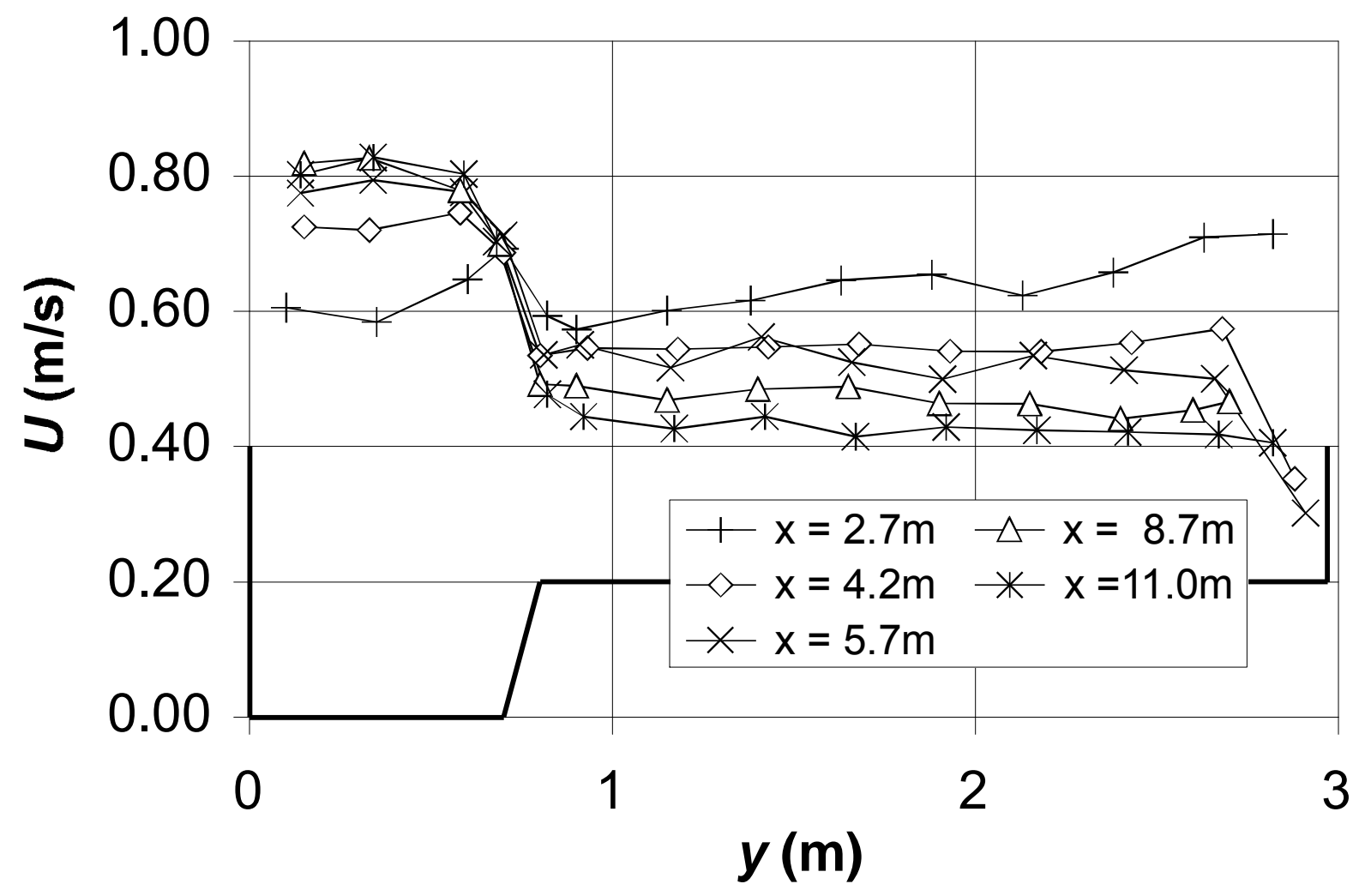

Fig. 3 


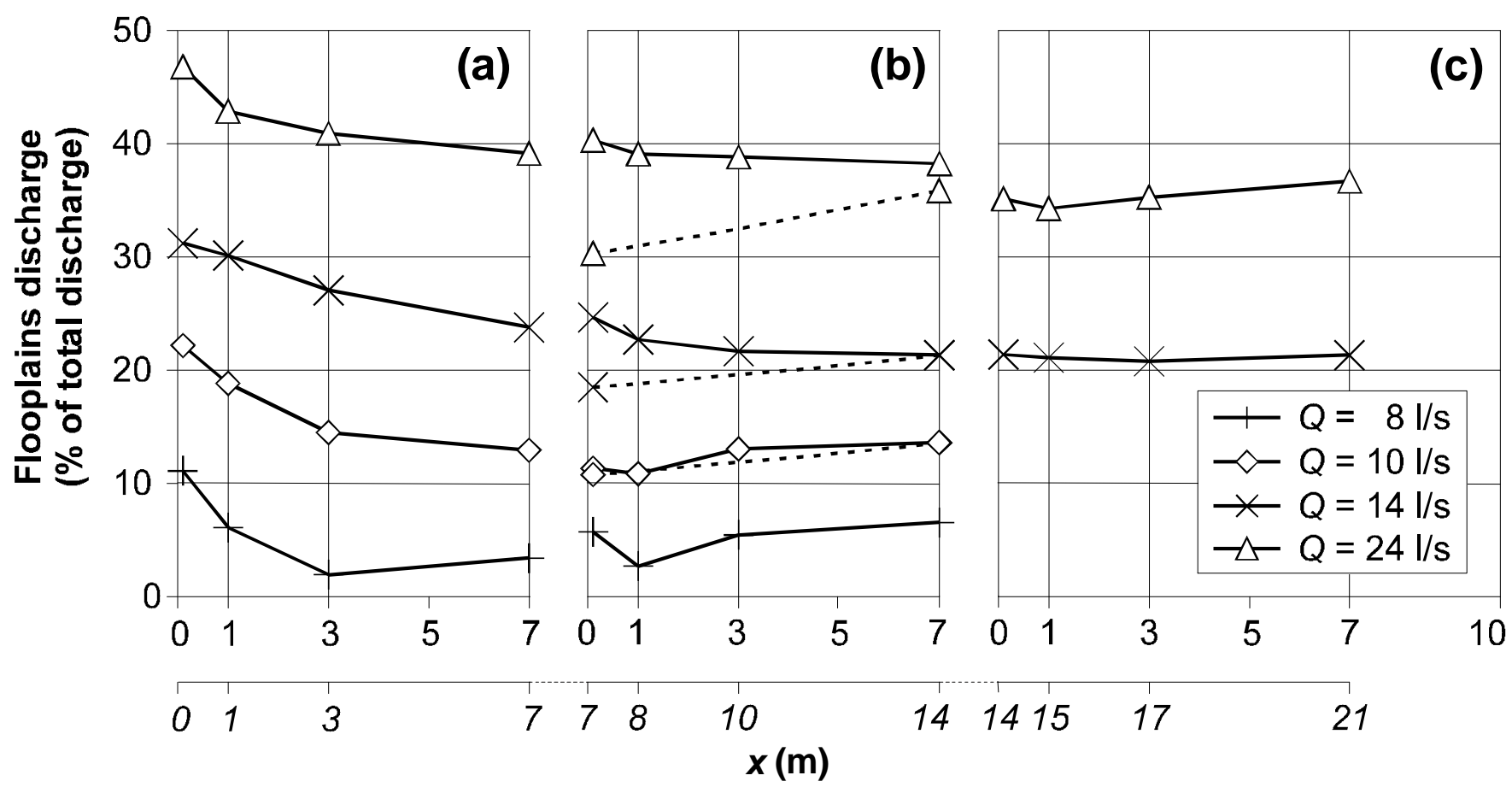

Fig. 4 


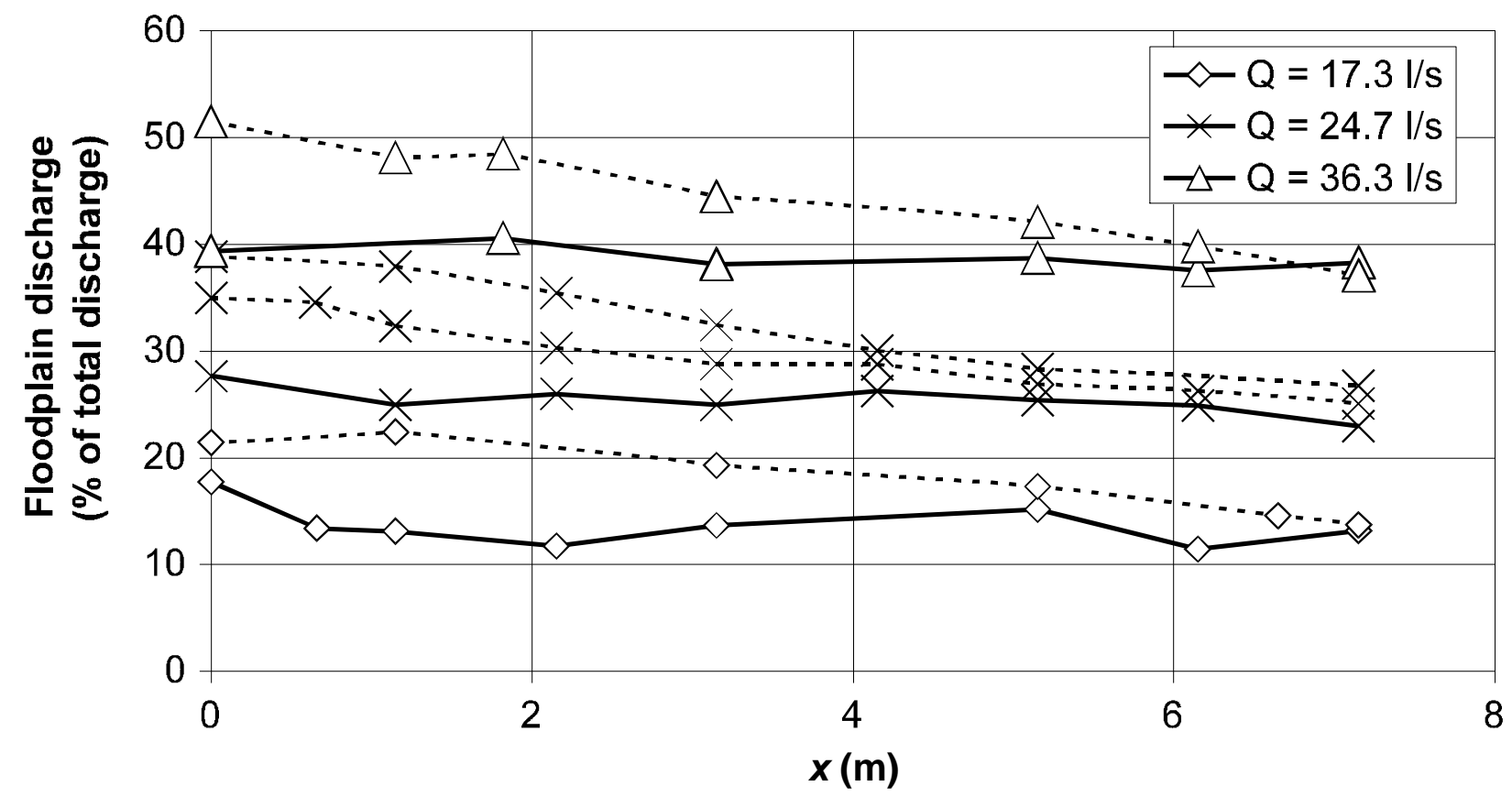

Fig. 5 